\title{
Structural Parallels between Vaeakau-Taumako and the Vanuatu Outliers: Capell Revisited
}

\author{
Åshild Næss \\ UNIVERSITY OF NEWCASTLE, AUSTRALIA
}

\begin{abstract}
This paper examines a set of structural parallels between Vaeakau-Taumako (Pileni), a Polynesian Outlier spoken in Temotu Province in the Solomon Islands, and the Vanuatu Outliers Emae, Ifira-Mele, and Futuna-Aniwa. It shows that these four languages share a set of structural features that is not, as a whole, shared by other known Polynesian languages; other languages may show one or two of the features under discussion, but not all four. It argues that the parallels are too detailed to be coincidental, and asks why it should be that just these four languages show such detailed similarities in structure. While it is not possible on the basis of the available data to decide whether the similarities should be assumed to result from shared origins or contact (or both), it is proposed that they may be seen as tentative support for the suggestion made by Bayard that the Vanuatu Outliers (and West Uvean) received their primary settlement from the Vaeakau-Taumako area, rather than directly from Triangle Polynesia.
\end{abstract}

1. INTRODUCTION. The precise origins and relationships of the Polynesian Outliers are subject to ongoing debate, restricted to no small extent by the lack of sufficient data or detailed descriptions for most of the languages involved. The Ethnologue (Lewis 2009) subdivides Nuclear Polynesian into two subgroups, East Polynesian and SamoicOutlier, with the Outliers assigned to two different subgroups of Samoic-Outlier: Ellicean, which consists of Kapingamarangi and Nukuoro of Micronesia, Nukumanu, Nukuria, and Takuu of Papua New Guinea, and Ontong Java (Luangiua) and Sikaiana of the central Solomon Islands, as well as the Triangle Polynesian language Tuvaluan; and Futunic, consisting of Rennell-Bellona in the Solomon Islands province of the same name, Anutan, Tikopian, and Vaeakau-Taumako ${ }^{1}$ in Temotu, the easternmost province of Solomon Islands, Emae, Futuna-Aniwa (West Futunan), and Ifira-Mele (Mele-Fila) of Vanuatu, and West Uvean (Fagauvea) of New Caledonia, as well as the Triangle Polynesian language East Futunan.

This subgrouping, with just one Triangle Polynesian language subgrouped with each group of Outliers, clearly implies a hypothesis about the origins of the various Outliers in different parts of Triangle Polynesia. At the same time, it represents a geographical divi-

1. Previously known in the literature as Pileni.

Oceanic Linguistics, Volume 51, no. 2 (December 2012)

(C) by University of Hawai'i Press. All rights reserved. 
sion as well, with the northern Outliers of Micronesia, Papua New Guinea, and the central Solomons falling into one group, and the southern Outliers of Rennell-Bellona, Temotu, Vanuatu, and New Caledonia into another. Contact between different Outliers is well documented (Kirch and Yen 1982), and so the fact that the subgroups also correspond to geographical groupings suggests that similarities found between Outliers within a putative subgroup may well be due to contact, as well as to shared retentions or shared innovations.

Marck (1999:113), on the other hand, suggests abandoning the Samoic-Outlier subgroup, which he finds unsubstantiated by reliable diagnostics, in favor of a "Samoan Ellicean-Eastern Polynesian" group, leaving, among others, the non-Ellicean Outliers as unclassified Nuclear Polynesian languages (Marck 1999:111). He further notes that “'Futunic' (non-Ellicean Outliers) languages have yet to be linked as a group by diagnostic methods and may have been the first Nuclear Polynesian languages to diverge from the others" (Marck 1999:113). Wilson (2012) suggests that the "Ellicean” Outliers, which he calls the Northern Outliers, form a subgroup with the East Polynesian languages, and notes that there are traditions of regular contact between the Northern Outliers and Tikopia; he suggests that this traditional annual voyage represents a remnant of an earlier pathway connecting the Northern Outliers both to the Outliers in the south and to parts of Triangle Polynesia beyond.

As far as the southern or Futunic Outliers are concerned, then, they are problematic in their classification both with respect to their relationship to other Polynesian languages and to the relationships within the group. Capell (1960:165) argues that grammatical parallels between Futuna-Aniwa, Ifira-Mele, and Vaeakau-Taumako are evidence for these languages forming a subgroup within the Outliers; Capell (1962) seems to suggest that Emae should be added to this group.

Capell's suggestions regarding the explanations for these parallels, which concern structures not apparently present in Triangle Polynesian languages, have generally not been accepted by Oceanic scholars. He considered the situation to be evidence against the hypothesis that the Outliers were colonized by westward back-migration from the core Polynesian areas once these had been settled, because "migrants (willing or unwilling) from the east could not bring back with them features that they did not possess. There is so much in F[utuna-]A[niwa], Mae, Pil[h]eni [=Vaeakau-Taumako] and other languages that has no parallel further east. How, then, could it be brought back from that direction?” (Capell 1962:46). In another publication, Capell expresses the opinion that "the conclusion seems to be forced on the student that FA represents (along with Pileni and presumably Fila-Mele) an archaic part of the Polynesian colonization, a relic left en route to Fiji and Polynesia" (Capell 1960:166).

This "remnant" theory of Outlier colonization is discussed in some detail by Bayard (1976:4ff.), who concludes that it is an unlikely scenario, and that the majority of evidence points towards the Outliers being settled by later migration from the core Polynesian areas; the latter is by now the established view.

The purpose of this paper is not to defend Capell's conclusion, but to examine in detail some of the properties on which it presumably built, and to try to establish what conclusions it is reasonable to draw from them. The paper explores two sets of detailed structural parallels between Vaeakau-Taumako (Pileni/Pilheni) and the Vanuatu Outliers 
Futuna-Aniwa, Ifira-Mele, and Emae. The starting point of the analysis is my own descriptive work on Vaeakau-Taumako, for which I have fairly detailed data. ${ }^{2}$ For Futuna-Aniwa, there is a reasonably detailed description available (Dougherty 1983). For Ifira-Mele and Emae, on the other hand, I have relied on brief grammatical sketches (Capell 1962 for Emae, Clark 2002 for Ifira-Mele), and so the comparison is on some points rather superficial. It nevertheless seems apparent that these languages do, on certain points of grammar, show parallels that appear not to be shared—at least not to the same extent — by other Polynesian languages. While this does not, as such, argue for a "remnant" theory of colonization, it does demonstrate that Vaeakau-Taumako and the Vanuatu Outliers share a number of features that do not appear to occur in Triangle Polynesian languages. A more nuanced analysis of the origins of these shared features will be attempted; I will suggest that some of them are shared retentions, while others may be shared innovations. I will argue that the parallels are too detailed to be accidental, and consequently are indicative of some sort of shared history, although whether this is a history of contact or of shared origins (or, as seems likely, a combination of the two) cannot be reliably established from the data.

2. THE POLYNESIAN OUTLIERS. The Polynesian Outliers are a group of fifteen Polynesian languages spoken in Melanesia and Micronesia, that is, west of the region known as the Polynesian Triangle where the majority of Polynesian languages are found. As noted above, the accepted account for the presence of this scattering of Polynesian language communities, mostly on small and marginal islands, in a region otherwise dominated by languages from other Oceanic subgroups, is that they arrived through back-migration from the Polynesian areas to the east, after these areas had first been settled in a west-to-east migration. This does not entail a single event of Outlier colonization; on the contrary, multiple voyages and points of origin, as well as sustained contact both between different Outliers and between them and their Triangle Polynesian homelands, must be assumed (Bayard 1976, Kirch and Yen 1982, Kirch 1984).

The Outlier language communities vary in size from well over 4,000 (Rennell-Bellona) to around 270 (Anutan; figures from www.ethnologue.com), while most are in the range of 700-1,500 speakers. Because of their location in the Melanesian/Micronesian region, many of the Outliers also have long histories of contact with neighboring non-Polynesian languages that may have affected both their vocabularies and their grammar; for example, Vaeakau-Taumako has various structural properties that appear to have arisen through influence from the neighboring Äiwoo language (Næss and Jenny 2011).

In general, the Outliers are fairly poorly described. Published grammars exist for Luangiua (Salmond 1974), Rennell-Bellona (Elbert 1988), Futuna-Aniwa (Dougherty 1983), and Vaeakau-Taumako (Næss and Hovdhaugen 2011), while shorter sketches are available for Emae (Capell 1962), Nukuoro (Carroll 1965), Anutan (Feinberg 1977), Sikaiana (Donner 1987), and Ifira-Mele (Clark 2002). Previous comparative work on the

2. Most of my work on Vaeakau-Taumako has been carried out in close collaboration with Even Hovdhaugen, and I gratefully acknowledge the influence of this collaboration on the present work, as well as Even's kind permission to continue to use his data for further research. This paper has also benefited from discussions with Alex François on the role of contact vs. internal change in explaining parallels such as those presented below. 
Outliers (Elbert 1965, Pawley 1967, Bayard 1976) has focused on vocabulary and sound correspondences. This paper focuses on a small set of structural features that, it will be shown, occurs in a small subset of the Outliers, but not in the rest of the Outliers nor in the languages of Triangle Polynesia. The account is necessarily sketchy, given the scarcity of available data for many Outliers, and my discussion is restricted to the languages for which I have been able to find sufficient data.

\section{Cia SUFFIXES AND THE PREPOSITION $e$}

3.1 THE GENERAL POLYNESIAN SITUATION. Within Polynesian, the functions of the so-called Cia suffixes, ${ }^{3}$ and the preposition $e$ and its cognates, largely depend on the morphosyntactic alignment of the language in question. In the accusative Polynesian languages, which are mainly those of the East Polynesian subgroup, the Cia suffixes function as passive suffixes, and $e$ as the marker of a demoted passive agent, as in the following examples from Māori: ${ }^{4}$

(1) MĀORI
a. E koohete ana a Huia i a Pani. TAM scold TAM PERS Huia OBJ PERS Pani 'Huia is scolding Pani.'
b. I koohete-tia a Pani e Huia. TAM scold-PASS PERS Pani by Huia
'Pani was scolded by Huia.'

(Bauer 1993:396)

Additional functions of the Cia suffixes sometimes occur as well, for example, in Marquesan, where the suffix - 'ia may be used to indicate a completed action, particularly with intransitive verbs (Cablitz 2006:128).

In the ergative Polynesian languages, cognates of $e$ function as the marker of ergative case. The Cia suffixes have a number of rather complex functions and have been subject to considerable discussion. In Samoan, for which there is a fairly extensive body of literature on the suffixes, they are described as having two main functions: (i) transitivizing (or "ergativizing" in the terminology of Mosel and Hovdhaugen 1992), deriving transitive verbs from certain intransitive verbs (Mosel and Hovdhaugen 1992:736), and (ii) forming "long forms" of already transitive verbs. Such long forms exist for all underived transitive verbs in the language and are used in a number of circumstances, such as in negative imperatives, in clauses with preverbal subject pronouns, in relative clauses with a relativized $\mathrm{A}$, with fronted ergative noun phrases (which do not take the ergative marker $e$, being marked instead by the "presentative" preposition 'o), in certain types of negative declarative clauses, in some types of adverbial purpose clauses, and in agentless clauses where the agent is to be interpreted as generic or unidentified (Mosel and Hovdhaugen

3. Consonant-ia, where the so-called thematic consonant depends on the root to which the suffix attaches; most languages have additional allomorphs such as - $a$ and/or -ina.

4. Nonstandard abbreviations used in glosses are: AG, agentive preposition; ASP, aspect; COLL, collective article; DES, desiderative; HYP, hypothetical particle; HORT, hortative; EMPH, emphatic particle; INCP, inceptive; OBL.PRO, oblique proform; PERS, personal article/marker; PREP, preposition; PRES, presentative; RED, reduplication; SUFF, suffix; TAM, tense-aspectmood; TNS, tense; TOP, topicalizing preposition. 
1992:747-61). Mosel and Hovdhaugen suggest that the relevant semantic generalization is that the short form is used when the focus is on the affectedness of the patient, the long form when the action implies a pragmatically salient agent, either (1) because the patient is not affected (as in negative imperatives), (2) because an implied agent is distinct from previously mentioned participants when the agent pronoun or NP is fronted, or (3) with an unexpected or inappropriate action when "the agent gains more importance than he or she would have otherwise" (Mosel and Hovdhaugen 1992:763). Other analyses that have been posited for the Cia suffixes in various languages are, for example, as markers of perfectivity, emphasis, or focus on an affected agent; the suggestion that it functions in Tuvaluan to overtly mark a clause as transitive under certain circumstances (Besnier 2000) will be further discussed in section 5 below.

3.2 VAEAKAU-TAUMAKO. In Vaeakau-Taumako, the Cia suffixes function as transitive suffixes that are obligatory on all transitive verbs, ${ }^{5}$ where "transitive verb" means a verb that takes a definite, affected object, and that requires the suffix $-i$ on its tense-aspect marker when its subject is 3sG. Cia-suffixed verbs contrast in most cases with unsuffixed verbs, which are either intransitive or "semi-transitive"; the latter term refers to a class of verbs that occur with a noun referring to a plural, indefinite, or generic object that is analyzed as being incorporated into the verb-phrase nucleus (Næss and Hovdhaugen 2011:69).

(2) VAEAKAU-TAUMAKO

a. Ko noho ne fana ika i thaupē na.

INCP stay PFV shoot fish LOC lagoon DEM.2

'He was shooting fish in the lagoon.'

b. Ko te kovā ne thū i te mui o na

TOP SG.SP heron PFV stand LOC SG.SP place POSS 3SG.POSS

thoka-na la, $\bar{e}, \quad$ ko-i fana-ia.

same.sex.sibling-3sG.Poss DEM.3 yes INCP-3sG shoot-TR

'There was a heron standing on his brother's grave, so he shot it.'

Unlike most Nuclear Polynesian languages, basic word order in Vaeakau-Taumako (and most other Outliers) is SVO. In this configuration, Vaeakau-Taumako shows no obligatory marking of any argument ([3a]; for the function of the "personal marker" $a$, see Næss and Hovdhaugen 2011:160-65, Næss 2011). When a transitive subject is postposed to the verb, however, it is marked with the preposition $e(3 \mathrm{~b})$.

(3) VAEAKAU-TAUMAKO

a. Mhatou ka ta-ia ala na a Kulingi na. 1PL.EXCL FUT hit-TR HYP DEM.2 PERS Kulingi DEM.2

'We will kill Kulingi.'

b. Ne-i kā-mai mhaua e te ngata na. PFV-3SG bring-come 1DU.EXCL AG SG.SP snake DEM.2

'A snake brought us here.' 
3.3 FUTUNA-ANIWA. Futuna-Aniwa is largely parallel to Vaeakau-Taumako in the use of the Cia suffixes and the preposition $e$. As in Vaeakau-Taumako, Cia suffixes in Futuna-Aniwa function as transitive suffixes appearing obligatorily on transitive verbs and indicating that the action affects a specific direct object (Dougherty 1983:102). The main difference appears to be that, while in Vaeakau-Taumako the marking of a postverbal transitive subject with $e$ is obligatory, in Futuna-Aniwa it is optional; the marker "emphasizes the subject, distinguishing it from other phrases in the sentence" (Dougherty 1983:42).

(4) FUTUNA-ANIWA
a. Avau kono asi.
1SG TNS check.up
'I'm going to do some checking up.'
b. Ta pitie ka-me-i asi-a ta fanua.
ART BDA TNS-ASP-SUFF check-TR ART island

'The BDA (British District Agent) has come to check up on the island.'

(Dougherty 1983:120)

(5) FUTUNA-ANIWA
a. Roroveka ne-i toua ta fare nei. Roroveka TNS-SUFF build ART house this 'Roroveka built this house.'
b. Ta fare ni toua e Roroveka. ART house TNS build PREP Roroveka 'The house was built by Roroveka.'

(Dougherty 1983:41, 43)

3.4 IFIRA-MELE. As in Vaeakau-Taumako and Futuna-Aniwa, transitive verbs in Ifira-Mele are obligatorily marked with a Cia suffix (Clark 2002:687). There is no marking of either argument when the clause has basic SVO word order, and alternative orders seem largely to be impossible; there does not appear to be a reflex of the preposition *e (Ross Clark, pers. comm.).

3.5 EMAE. Capell (1962) describes the Cia suffixes in Emae as transitive suffixes that "serve usually to link the base with its goal" (Capell 1962:20). While some verbs never appear to take a suffix, "in most cases ... a suffix - $a$ [with allomorphs -na, -kina, and -Cia] indicates the expectation of a goal" (Capell 1962:23). While few systematic examples of the contrast are given, it appears that the Emae suffixes have a function quite similar to that described above for Vaeakau-Taumako, Futuna-Aniwa, and Ifira-Mele.

Capell (1962:6) also notes that Emae shows SVO word order, but does not describe any alternative orders nor any possible cognate of the preposition $e$. It is, therefore, not known whether such a preposition, if it exists in the language, patterns similarly to Vaeakau-Taumako and Futuna-Aniwa.

3.6 OTHER OUTLIERS. The language that most closely parallels VaeakauTaumako and the Vanuatu Outliers on these points is West Uvean of New Caledonia. In West Uvean, the Cia suffixes function as obligatory transitive suffixes (Alexandre Djoupa, pers. comm.), and there is a marker $a$ that is used to mark postverbal subjects, 
but this appears to be a more recent development and not a cognate of $e$ (Claire MoyseFaurie, pers. comm.).

The function of the -Cia suffixes in Anutan is not clear, but it is obvious that they are not obligatory transitive suffixes in the manner of those found in Vaeakau-Taumako and the Vanuatu Outliers. They are clearly not required in transitive clauses with a specific affected object, and the difference between examples such as (6a) and (6b) is not clear:

(6) ANUTAN

a. Ko ia ne na rangai te raakau nei. 'He pulled up this tree.'

b. Ko ia ne na rangai-a poki te kope. 'He also pulled up the bamboo.'

(Feinberg 1998:22)

The preposition $e$ in Anutan patterns to some extent with its cognates in VaeakauTaumako and Futuna-Aniwa in that it is frequently found when a transitive subject is postposed to the verb (7a). There are also, however, examples of postposed transitive subjects without $e(7 \mathrm{~b})$, as well as of postposed subjects of apparently intransitive verbs taking $e$ (7c). It does not appear to be possible to use it on a preverbal subject (Rick Feinberg, pers. comm.).

(7) ANUTAN

a. E puka mau e Manu. 'Manu held it fast.'

b. Karanga mai rea na mmana. 'Her father asked.'

c. Ko konokono e Metikitiki. 'Metikitiki became angry.'

(Feinberg 1998:26, 34, 35)

To some extent, then, the use of Anutan $e$ may be similar to what is found in FutunaAniwa, where its use is common but not obligatory on postposed transitive subjects, though its appearance in intransitive clauses does not have any parallels in the languages under discussion here.

Firth (1985:xxxiv-xxxv) describes the Cia suffixes in Tikopian as "passive" or "perfective." Their use is clearly complex, and examples can be found for which both a "passive" and a "perfective" interpretation seems likely. For example, for the suffixed verb akona in (8b), the patient, the person taught, is clearly the subject, whereas this is not the case for the unsuffixed verb in (8a):

(8) TIKOPIAN

a Kuou ne ako ki a ke. 'I taught you.'

b Te pure i Rarovi e akona i toku mana. 'The elder of Rarovi was taught by my father.'

(Firth 1985:7)

There are other examples where the difference is much less clear, but which clearly demonstrate that, unlike in Vaeakau-Taumako, a suffix is not required for a verb with a definite affected object: 
(9) TIKOPIAN
a. Tuki te ngaruenga.
'Pound the pudding.'
b. na kapakau ne mau tukia
'his shoulder that we two pounded'

(Firth 1985:549-50)

Early (1981:119) suggests that one function of the Cia suffix in Tikopian may be to signal the lack of an overt subject, though he notes that the available data are insufficient to account for all the uses of the suffix.

The preposition $e$ is described as an "agency marker" (Firth 1985:30). Early (1981: 114) gives the basic word order of Tikopian as being VSO, and $e$ as marking subjects in "Canonical-Agentive” transitive constructions (Early 1981:118); this would clearly be a different use of the preposition from that found in the SVO languages discussed above. Early also notes that data from one speaker show frequent SVO order and no $e$-marking in these constructions (Early 1981:114-15), and suggests that this may be indicative of ongoing linguistic change, but there are no data available to corroborate this or indicate what, if anything, would be the function of $e$ in such a changed system.

In Rennell-Bellona, Elbert (1988:83-86) describes the Cia suffixes as “goal focus” markers, and notes that constructions with the suffixes are often, but not necessarily, translatable as English passives; they "emphasize action upon a goal rather than action by an actor" (Morton 1962, quoted in Elbert 1988) and are in some cases, though not in all, incompatible with an overtly expressed actor. This appears to be rather different from the situation in Vaeakau-Taumako and the Vanuatu Outliers, where the suffixes are obligatory on all or most transitive verbs. $E$ functions in Rennell-Bellona as a subject marker for a subset of transitive verbs (Elbert 1988:29-31), that is, its use is determined by the verb of the clause, not by the relative position of subject and verb.

In Sikaiana, the Cia suffixes appear to have mainly a passivizing function, with the preposition e marking the demoted passive agent (Donner 1987:24).

For Nukuoro, Carroll and Soulik (1973:812) describe the Cia suffixes as "perfective suffixes," noting that this "follows the usage of George Milner, and is chosen for exactly the same reasons he adduces in his Samoan Dictionary"; this is presumably to be interpreted as meaning that the Nukuoro Cia suffixes have similar functions as their Samoan counterparts. The preposition $e$ is glossed as 'by' in Carroll and Soulik (1973:75), with no further information given. Carroll (1965:220) states that $e$ "indicates the actor in a passive construction," giving the contrasting examples Ia e gage de nui 'he climbs the tree' and De nui e gagea e ia 'the tree was climbed by him', with the suffix - $a$ on the verb gage 'climb'. The description of the function of the Cia suffixes in this source is, however, rather unclear. They are claimed to be "more profitably considered 'transitivizing' than 'passive”" (Carroll 1965:221), but their use is said to "indicate that the action is or will definitely be accomplished, in that it is the responsibility or intention of someone to do so" (Carroll 1965:222). Presumably, it is this use that motivates the description of the suffixes as "perfective" in Carroll and Soulik (1973), though the "passive” function and the relationship of the suffixes to the preposition $e$ remains unclear.

For Kapingamarangi, Lieber and Dikepa (1974:xliii) note that the preposition $e$, glossed as 'agent', is “used with certain bases (usually verbs) to indicate subject or 
agent.” The examples given show a double occurrence of the subject NP, one preverbal and one postverbal and marked with $e$; possibly this indicates some sort of emphatic function.

(10) KAPINGAMARANGI

a. Au de iloo e au. 'I don't know.'

b. Au e moina $\mathbf{e}$ au goe.

'I cherish you.'

The Cia suffixes are for the most part defined as variants of $a_{3}$, defined as an "imperative (transitivizing) suffix" (1974:3); the form -ina is described as a "transitive suffix (normally used as an imperative suffix)" (1974:109). Since no examples of their use are given, very little can be deduced about their exact function from this source. However, Rutter (2002) claims that the Cia suffixes act like transitive suffixes in Kapingamarangi, but that this use is largely restricted to future or unrealized clauses; in addition, it is occasionally used in imperatives, though Rutter does not specify whether this applies exclusively to transitive imperatives.

3.7 SUMMARY. The use of the Cia suffixes as productive transitive suffixes, found in Vaeakau-Taumako, Futuna-Aniwa, Emae, and Ifira-Mele, has few direct parallels in other known Polynesian languages. The closest parallel is clearly in West Uvean, which shows essentially the same kind of system. Kapingamarangi may to some extent be similar, in that Cia suffixes in this language are described as "transitive," but their highly restricted use means that their overall function is somewhat different in this language.

The use of the preposition $e$ to obligatorily or optionally mark a postverbal transitive subject is attested in Vaeakau-Taumako and Futuna-Aniwa, though not in Ifira-Mele, where the preposition appears not to exist; data on this point are missing for Emae. Anutan shows a similar pattern for the use of this preposition, though it is not clear what governs the presence vs. absence of the preposition for this language; note that it also appears with postverbal intransitive subjects, a distribution not found in the languages under discussion here.

Historically, this use of $e$ presumably relates to the fact that, in VSO languages such as Samoan and Tuvaluan, fronted transitive subjects normally do not take the ergative preposition (cf. section 5 below). From a synchronic perspective, however, the function of $e$ in the SVO languages Vaeakau-Taumako and Futuna-Aniwa is clearly different: it marks the subject of a transitive clause with nonbasic word order, that is, when the subject cannot be unambiguously identified from word order alone (Næss and Hovdhaugen 2011:313-16, Næss 2011, n.d.).

\section{THE POSSESSIVE SYSTEM}

4.1 POSSESSIVES IN POLYNESIAN. In general, Polynesian languages lack the otherwise pervasive Oceanic distinction between "direct" and "indirect" possessives, where direct possessives show possessive marking directly on the possessed noun, while indirect possessives are constructed with a distinct possessive morpheme (often called a 
possessive classifier; cf. Lichtenberk 1983) on which marking for person/number of the possessor appears. Semantically, the direct/indirect distinction corresponds roughly to the distinction between inalienable and alienable possession, with direct possessives typically used for kinship terms, body part terms, and other inalienable relationships, whereas terms for alienably possessed items take indirect possessive marking.

Instead, the formal distinction in most Polynesian languages is between so-called Opossessives and A-possessives, labeled for the form of the respective possessive morphemes. The semantic distinction between the two possessive types have variously been labeled in terms such as dominant/subordinate, controlled/uncontrolled, active/passive, and the like (Clark 2000:265).

Most Polynesian languages have several sets of pronominal possessive forms. Most relevant for the present purposes: there is generally a prenominal set, constructed with a bound form of an article, the possessive morpheme $o / a$, and a suffix indicating the person/number of the possessor; and a postnominal set, analyzed in some languages as a prepositional phrase consisting of a possessive preposition $o$ or $a$ followed by a pronoun indicating person/number of the possessor.

(11) SAMOAN
a. 'o l-o-u fale
PRES ART-POSS-2SG house
'your house'
b. 'o le fale $\mathbf{o}$ 'oe
PRES ART house POSS 2SG
'your house'

(Mosel and Hovdhaugen 1992:277)

For most Polynesian languages, there appears to be little if any semantic difference between the use of preposed or postposed possessive forms, although in some languages there is a difference in emphasis or definiteness (Clark 2000:260).

Wilson (1982:35-36) notes that a number of Outliers show direct possessive marking for singular possessors with a handful of kinship terms, and that Triangle Polynesian languages generally retain a petrified 3SG possessive suffix *-na with these terms. He considers the Outlier suffixing strategy to be a shared retention from Proto-Polynesian (PPN), and accordingly reconstructs the following set of directly possessed kinship terms for PPN: *tahi-na 'younger sibling of the same sex', *tuaka-na 'older sibling of the same sex', *tina-na 'mother', *tama-na 'father', *makupu-na 'grandchild', *tupu-na 'grandparent' (Wilson 1982:37). He suggests that this class of kinship terms could alternately be marked as possessed with an O-possessive pronoun preceding the -na suffixed form of the noun, and that it is this pattern that has prevailed in the majority of Polynesian languages, which have lost direct possession altogether.

(12)

$$
\begin{aligned}
& \text { PROTO-POLYNESIAN } \\
& *_{\mathrm{t}-\mathrm{O}-\mathrm{u} \text { tama-na }} \\
& \text { ART-POSS-2SG father-SUFF } \\
& \text { 'your father' }
\end{aligned}
$$

(Wilson 1985:97)

Wilson further notes that, for other kinship and body-part terms, that is, those generally taking direct possession in other Oceanic languages, direct suffixation would have 
been lost by the time of PPN; they would be distinct from the class of kinship terms described above only in taking prenominal O-possessive pronouns only, with no suffix:

(13) PROTO-POLYNESIAN

$$
\begin{array}{ll}
* \mathrm{t}-\mathrm{o}-\mathrm{u} \text { mata } & * \mathrm{t}-\mathrm{o}-\mathrm{u} \text { fosa } \\
\text { 'your eye' } & \text { 'your son' }
\end{array}
$$

Wilson presents two alternative hypotheses for the source of O-marking with PPN kinship and body part terms. The first is that it is simply an extension of the A/O posssessive system to these classes of nouns following the loss of direct suffixation. Given the function of O-possessives as marking relationships whose initiation is beyond the possessor's personal control, this hypothesis adequately accounts for the use of the Opossessive with body parts and most kinship terms, though Wilson notes that there are kinship terms for which the A-possessive might be expected (for example, *fosa 'son', *mokupu-na/makupu-na 'grandchild'), as the relationships in question could be considered to come about through the agency of the possessor (Wilson 1982:97).

The second hypothesis is that pre-PPN had a distinct preposed possessive marker (different from early Oceanic *na-, *ka-, and *ma-) for an "irregular" (that is, not directly possessed) class of kinship and body-part terms that developed into PPN O-marking. This hypothesis builds on comparison with non-Polynesian Oceanic languages that do show a distinction between regular and irregular kinship and body-part terms, such as Standard Fijian, Western Fijian, and Nguna of Vanuatu (Wilson 1982:97-99; cf. 4.7 below).

It should be noted that Clark (1994:118-19) appears to consider the presence of direct possessive marking in certain Outliers not as a shared retention, but as resulting from contact with non-Polynesian Oceanic languages that do have direct possession: "in at least three languages (Pileni, Mele-Fila and West Futuna) these suffixes have regained their meaning and use at least with this small class of words. ... It can hardly be coincidence that the languages in which this has occurred are among the group of heavily influenced Outliers" [i.e., influenced by contact with non-Polynesian languages - author's note]. As will be shown below, however, the parallels between these languages in the domain of possessive marking go beyond the use of direct possession, including also the use of prenominal possessives to mark inalienable possession.

4.2 POSSESSIVES IN VAEAKAU-TAUMAKO. Vaeakau-Taumako shows direct possession with the following kinship terms (cited here in the 3sG form): tamana/ mhana 'father', hinana/nhana 'mother', thokana 'same-sex sibling', thupuna 'grandparent', and mokupuna 'grandchild'. These terms take the singular possessive suffixes -ku '15G', -u '2sG', and -na '3sG'; with dual and plural possessors, they take a possessive prepositional phrase consisting of a possessive preposition plus appropriate dual or plural possessive pronoun: hina a laua 'their (DU) mother', thama a latou 'their (PL) father'. Alternatively, these nouns may take the 3sG suffix -na in combination with a prenominal possessive pronoun or possessive prepositional phrase:

(14) VAEAKAU-TAUMAKO
a. tala-nga $\mathrm{i}=\mathrm{a}$
t-o-ku
thupu-na
tangata
tell-NMLZ LOC=PERS SG.SP-POSS-1SG.POSS
grandparent-3sG.POSs man
'stories from my grandfather' 


\section{b. mha-na 0 te memea \\ father-3SG.POSS POSS SG.SP child \\ 'the child's father'}

The rest of the nominal lexicon falls into two groups as far as possessive marking is concerned. Kinship and body-part terms take prenominal possessive pronouns, as in (15).

(15) VAEAKAU-TAUMAKO
a. T-o-ku tungane ne-i tapeo-ina mhaua.
'My brother treated us badly.' SG.SP-POSS-1SG.POSS brother PFV-3SG bad-TR 1DU.EXCL
b. O-na toto no tele. POSs-3sG.Poss blood IPFV run 'Her blood was flowing.'

Other nouns, however, take postnominal possessives:

(16) VAEAKAU-TAUMAKO
a. Tha ka 1DU.INCL.HORT FUT go.PL to house ki thaunga o-ku. 'Let's go to my house.'
b. A iau no lek-atu po ke-i toki-a te taveli PERS 1SG IPFV go-go.out COMP HORT-3SG plant-TR SG.SP banana a-ku i mua na.
Poss-1sG.Poss Loc
'I will go and plant my banana over there.'

In other words, in Vaeakau-Taumako the distinction between prenominal and postnominal possessives corresponds to the semantic distinction between inalienable and alienable possession. Indeed, minimal pairs can be found where the use of one or the other possessive construction corresponds to a semantic difference. In the examples in (17) and (18), the possessee in the (a) examples is construed as part of the possessor, that is, an inalienable relationship (food growing on the pumpkin, fish living in a certain place), and takes prenominal possessive pronouns. The (b) examples, by contrast, refer to possession proper, and have postnominal possessives.

(17) VAEAKAU-TAUMAKO
a. Ko ēke na ko-i av av-ange o-na kaikai na. INCP grow DEM.2 INCP-3SG RED give-go.along POSs-3sG.POSS food DEM.2 '(The pumpkin) grew and bore fruit (lit., gave its food).'
b. E fie-kai, a ko-i to-a a kaikai a-na, ko kai. GENR DES-eat then INCP-3SG take-TR COLL food POSS-3SG.POSS INCP eat 'He got hungry, and he took his food and ate.'

(18) VAEAKAU-TAUMAKO
a. Lhatu $\bar{o}$ atu loa $\mathrm{o}$ hangota $\mathrm{i}$ Malimi dekina 3PL go.PL go.out EMPH to fish LOC Malimi because mua ne ohi ai o-na ika. place DEM.1 finish OBL.PRO POSS-3SG.POSS fish 'They are going to fish at Malimi, because there are no more fish here (lit., this place, its fish are finished.)' 
b. Lhatu-ko to-a ange a ika, a ika a-na na. 3PL-INCP take-TR go.along COLL fish COLL fish POSS-3SG.POSS DEM.2 'They took the fish, his fish.'

4.3 POSSESSIVES IN FUTUNA-ANIWA. In Futuna-Aniwa, the following kin terms are directly possessed: tamana 'father', jinana 'mother', tojinana 'uncle', tupuna 'grandparent', fugona 'niece or nephew (of a woman)', and tampuna 'grandchild' (Dougherty 1983:77).

Futuna-Aniwa has a set of "article-based" preposed possessive pronouns and a set of "non-article-based" postposed possessive pronouns; the two constructions are, according to Dougherty (1983:65) synonymous, and apply to the same nouns, as illustrated in (19).

(19) FUTUNA-ANIWA
a. tiaku pakasi
1sG.POss pig
'my pig'
b. ta pakasi amua ART pig 2DU:POSS 'our (DU) pig'

(Dougherty 1983:63, 66)

However, Futuna-Aniwa has a distinct set of "inalienable" possessive pronouns for singular possessors that are prenominal and are used with kinship terms (those not included in the directly possessed set), body-part terms, and other part-whole terms. The differences between the regular article-based possessive pronouns and the inalienable possessive pronouns are shown in tables 1 and 2 . As can be seen, the dual and trial forms are identical in the two tables, except for the third person forms; but the article-based set has alternate A-possessive forms (ruaku, ruau, ruana; takaku, takau, takana), whereas the inalienable set does not.

The difference between Vaeakau-Taumako and Futuna-Aniwa, then, is that where in Vaeakau-Taumako preposed possessives are used for inalienable possession and postposed possessives for alienable possession, Futuna-Aniwa has two sets of preposed

\section{TABLE 1. FUTUNA-ANIWA ARTICLE-BASED POSSESSIVE PRONOUNS (O-based possessive paradigm, singular possessives only) (Dougherty 1983:62)}

\begin{tabular}{l|llll}
\multicolumn{1}{c|}{ POSSESSOR } & \multicolumn{4}{c}{ NUMBER OF POSSESSED ITEM } \\
NUMBER PERSON & SINGULAR & DUAL & TRIAL & PLURAL \\
singular 1st & tioku & ruoku & takoku & ioku \\
singular 2nd & tiou & ruou & takou & iou \\
singular 3rd & tiona & ruona & takona & iona
\end{tabular}

TABLE 2. FUTUNA-ANIWA INALIENABLE POSSESSIVE PRONOUNS (Dougherty 1983:73)

\begin{tabular}{l|llll}
\multicolumn{1}{c|}{ POSSESSOR } & \multicolumn{4}{c}{ NUMBER OF POSSESSED ITEM } \\
NUMBER PERSON & SINGULAR & DUAL & TRIAL & PLURAL \\
singular 1st & tuku & ruoku & takoku & oku \\
singular 2nd & tou & ruou & takou & ou \\
singular 3rd & tano, tan & ruano & takano & ano
\end{tabular}


possessives, one for alienables and one for inalienables. As in Vaeakau-Taumako, postposed possessives mark alienable possession.

4.4 POSSESSIVES IN IFIRA-MELE. In Ifira-Mele, the directly possessed kinship terms include tama- 'father', atna- 'mother', tupu- 'grandparent', makupu- 'grandchild', figo(a)- 'parent/child-in-law', and tai- 'sibling of the same sex' (Clark 1978:918). For the rest of the nouns, there is a distinction between "intrinsic" possession (roughly, inalienable possession) and "contingent" possession (roughly, alienable possession): intrinsic possession with a pronominal possessor takes a prenominal possessive pronoun, whereas contingent possession is marked by a postnominal possessive pronoun or prepositional phrase (Clark 2002:685-86):

(20) IFIRA-MELE
a. Intrinsic possession
tno-usu
3sG-nose
'his/her nose'
b. Contingent possession
te-fare neaku
SG.DEF-house POSS.1SG
'my house'
c. Contingent possession
a-tara na taateu
PL.DEF-language POSS 1INCL.PL
'our language'

(Clark 2002:685-86)

4.5 POSSESSIVES IN EMAE. Emae has direct possession for singular possessors with the kin terms tamana 'father' and hinana 'mother', with the added twist of suppletive first-person forms ( $p a$ : 'my father', nau 'my mother') (Capell 1962:15). Other kin terms take prenominal possessive pronouns (Capell 1962:16). No postnominal possessive pronouns are described in the source. Capell does note, however, that there is an alternative 3sG possessive pronoun a:no (rather than the expected a:na); the conditions for the use of this form are not described, though the one example given is with the noun tafito 'root', which indicates a part-whole relationship. Possibly there is a parallel to the Futuna-Aniwa inalienable possessive pronouns with the 3sg form tano (cf. above).

4.6 POSSESSIVES IN OTHER OUTLIERS. From the available information, while some other Outliers also show a small class of directly possessed kinship terms, none appears to distinguish between inalienable possession marked by prenominal possessives and alienable possession marked by postnominal possessives.

Anutan, one of the two Outliers geographically closest to Vaeakau-Taumako, has alternative pre- and postnominal possessives in the dual or plural, but only prenominal possessive pronouns for singular possessives; no semantic difference between the two constructions for dual/plural possessor is indicated in the source, and indeed it is clear from the examples that a given noun can appear with either construction (Feinberg 1977: 18-19). As far as can be established from the available sources, Anutan does not show 
direct possession on any kinship terms. Feinberg (1977), while providing a fairly detailed discussion of kinship terminology, does not mention the existence of possessive suffixing for any of them, and indeed specifies toku tupuna, with a preposed possessive pronoun, as the term for "my grandfather" (note that tupu- 'grandparent' is among the directly possessed kin terms in most of the Outliers that have them), and the texts in Feinberg (1998) consistently use na tamana, with a preposed possessive pronoun, for 'his father'.

For Tikopian, neither Early (1981) nor Firth (1985) gives any indication that a set of postnominal possessives exists; Ray (1920:211) states that possessives precede the noun. However, the singular possessor pronouns oku, ou, ona, which are normally used with plural possessed items, may be used with body parts and certain kinship terms to indicate a singular possessee (Firth 1985); this may be an indication of a distinct set of prenominal possessive pronouns for kinship terms, similar to that found in Futuna-Aniwa.

In West Uvean, only a single kinship term, aava 'spouse, husband', takes direct possessive marking (Moyse-Faurie 2000:252). There are both prenominal and postnominal possessive pronouns, but the difference between them relates to definiteness and identifiability, with the postnominal forms having an identificational function ('the $\mathrm{X}$ which is mine'; Alexandre Djoupa, pers. comm.).

Sikaiana appears from the description in Donner (1987) to have preposed possessive pronouns only. Capell (1936:10) notes that there is a special form of the 2SG possessive pronoun only, "to indicate relationships and close possession, but its use seems a little uncertain"; this must presumably be seen as parallel to the Futuna-Aniwa inalienable pronouns.

Rennell-Bellona has both prenominal and postnominal possessive pronouns; the difference between them is described as being one of definiteness, with toku hage meaning 'my house', while te hage o'oku 'my house' implies reference to one of a set, that is, 'one of my houses' (Elbert 1988:177, Clark 2000:260-61). In addition, the language has a set of six directly possessed kinship terms: tupuna 'grandfather', tamana 'father', tinana 'mother', tu'aatinana 'mother's brother', taina 'man's younger brother', and makupuna 'grandson' (Elbert 1988:112). Rennell-Bellona, then, patterns with Vaeakau-Taumako and the Vanuatu Outliers in having a small set of directly possessed kinship terms, but not in having a special set of prenominal possessives for other inalienably possessed nouns.

Luangiua has both prenominal and postnominal possessives, but they appear to be applicable to the same set of nouns, and no semantic difference between them is indicated in the source (Salmond 1974:217-18). Capell (1936:10) suggests that there are distinct prenominal inalienable possessives in the first and second persons only.

For Nukuoro, Carroll and Soulik (1973) only list prenominal possessive pronouns. Carroll (1965:217) cites a couple of examples with what appear to be postnominal possessives, but gives no indication as to what, if anything, is the difference between them and the prenominal possessives. Likewise, Lieber and Dikepa (1973) describe both prenominal possessive pronouns and a construction consisting of postnominal preposition $a / o+$ pronoun in Kapingamarangi, but do not indicate any semantic difference between them.

4.7 POSSESSIVES IN WESTERN FIJIAN. In the possessive domain, a striking parallel to the situation in Vaeakau-Taumako and the Vanuatu Outliers is found in the Western Fijian languages. Western Fijian differs from Eastern Fijian in having lost 
suffixed direct possession for all but a few kin terms (Geraghty 2000:245). At the same time, Western Fijian has prefixed possessive pronouns for nonkin inalienable nouns, a fact that Geraghty (1983:221) claims to be "virtually without parallel in Oceanic languages." However, in purely structural terms, the Western Fijian possessive system is clearly closely parallel to that found in the Outliers under discussion here, combining as it does a small set of directly suffixed possessed kinship terms with prenominal possession for other inalienably possessed nouns such as part-whole terms, for example, Nakoroboya qu-drā (1sG-blood) 'my blood' (Geraghty 1983:221). It is, of course, possible that this apparent parallel is a coincidence, though it should be noted that Wilson (1982) uses Western Fijian as a witness for his tentative reconstruction of a preposed possessive marker for an "irregular" class of kinship and body-part terms in pre-PPN.

4.8 SUMMARY. There are two structural properties in the domain of possession that group Vaeakau-Taumako and the Vanuatu Outliers together. The first is the existence of direct possessive marking for a small set of kinship terms. The second is the existence of a distinct set of prenominal possessive pronouns used to indicate inalienable possession with indirectly possessed nouns, in contrast either with another prenominal set marking alienable possession or with postnominal possessive pronouns.

Both of these properties occur in other Outliers as well. Tikopian and Rennell-Bellona both have direct possessive marking on certain kinship terms. Tikopian may also have a distinct prenominal possessive set used for inalienable possession; in Rennell-Bellona, on the other hand, the only contrast appears to be between prenominal possession marking a definite, unique possessee vs. postnominal possession marking the possessee as one member of a set. A similar contrast appears to be encoded by the two types of possessives in West Uvean. Sikaiana and Luangiua may have a limited set of distinct prenominal inalienable possessives - Luangiua in the 1st and 2nd persons, Sikaiana in the 2nd person only.

The existence of a systematic distinction between alienably and inalienably possessed nouns, related to the position of the possessive pronoun in the noun phrase, may be considered evidence in favor of the second of Wilson's hypotheses concerning the marking of kinship and body-part terms in PPN, namely that it originates in a pre-PPN system of distinct classes of "regular" and "irregular" kinship and body-part terms. Crucially, the marking of "irregularly" possessed kinship and body-part terms in Vaeakau-Taumako and the Vanuatu Outliers - in this context to be understood as those not taking direct possessive marking - is not linked to the a/o distinction, which might be seen as a semantically regular extension, but to the prenominal position of the possessive marker in question.

5. DISCUSSION AND CONCLUSION. In terms of the structural properties discussed in this paper, a subset of the "Futunic" Outliers appears to group together as distinct from the rest. Vaeakau-Taumako and the Vanuatu Outliers Emae, Ifira-Mele, and Futuna-Aniwa share a set of structural features that is not found in the other Outliers, or for that matter in Triangle Polynesian languages:

- the use of the Cia suffixes as transitive suffixes that are obligatory on all or most transitive verbs; 
- the use of the preposition $e$ to mark postverbal transitive subjects (note that Ifira-Mele does not allow alternative word orders and so does not share this feature; data are missing on this point for Emae);

- the existence of a small class of directly possessed kinship nouns; and

- a distinction between inalienable nouns, which take prenominal possessive marking, and alienable nouns, which take postnominal possessive marking (note that data on this point are uncertain for Emae).

It should be noted that few, if any, of these features are unique to this set of languages; most individual features do occur in one or more other Outliers. Thus, Tikopian and Rennell-Bellona also have direct possession of certain kinship terms; Tikopian, Sikaiana, and Luangiua may have a distinct pronominal possessive for inalienables in some cases (typically only for the 1st and/or 2nd person singular). The Cia suffixes certainly have functions related to transitivity in a number of Polynesian languages, both Triangle and Outlier, but apart from Vaeakau-Taumako, Futuna-Aniwa, Ifira-Mele, and Emae, West Uvean is the only other language in which they function as obligatory markers of verbal transitivity. There is not, then, a clean break between these four languages and the rest of the Outliers; other languages may show one or two of the features under discussion, but only these four languages appear to show all of them. The question is how this situation has arisen.

If Wilson is correct in reconstructing the direct possessive to PPN, then presumably these are retentions in the languages under discussion. Clark's alternative hypothesis of the direct possessives resulting from influence from neighboring Melanesian languages is not implausible as such, but given the number of Outliers that show direct possession, as well as the fact that it is generally found with approximately the same etyma across these languages, it seems unlikely that they would each have developed it from individual instances of contact. Note further Wilson's (1982:39) argument that the form of the 2SG suffix found with the directly possessed kinship terms is $-u$, suggesting a Polynesian origin, rather than the common Oceanic form -mu; and that the restricted distribution of direct possession in all the Outliers in which it occurs is suggestive of retention rather than borrowing (Wilson 1982:40).

Again, if Wilson's suggestion of a distinct pre-PPN possessive marking type for an irregular class of kinship and body-part terms is correct, this would plausibly be the source of the distinct prenominal markers for inalienable possession found in these languages, and would be another shared retention. Note that, as far as this feature is concerned, there is nothing to suggest that a distinction between prenominal marking for inalienable possession vs. postnominal marking for alienable possession would be characteristic of the Melanesian languages with which the Outliers in question have been in contact; there is certainly no such distinction in Äiwoo, the Melanesian language from which Vaeakau-Taumako has otherwise borrowed a number of structural features. It seems more plausible that, as Wilson suggests, a distinct prenominal marking type was present in (pre-)PPN, and has been retained in the Outliers under discussion. The existence of a closely similar pattern in Western Fijian may be additional evidence for this, if one accepts it as a genuine parallel.

The function of the Cia suffixes in PPN has been the subject of extensive debate. In a fairly recent contribution, Pawley (2001) argues that while the Ci part of the suffix uncon- 
troversially reflects the Proto-Oceanic transitive suffix, the - $a$ stems from a Proto-Eastern Oceanic suffix *-a deriving stative verbs referring to a state resulting from a prior event, that is, having "the grammatical and semantic force of a 'passive participle"” (Pawley 2001:212). That is, the Polynesian forms in *Cia, *a, and *ina reflect Proto-Eastern Oceanic passive participles (Pawley 2001:214).

If Pawley is right, the use of the Cia suffixes as productive transitive suffixes in Vaeakau-Taumako, Emae, Ifira-Mele, and Futuna-Aniwa would appear to be an innovation. Næss (n.d.) argues that this innovation in Vaeakau-Taumako is the result of the wordorder change from VSO to SVO, with the starting point being a system similar to that found in present-day Tuvaluan, where the Cia suffixes mark a verb as overtly transitive "when the valency of the transitive clause is somehow put into question by syntactic and semantic factors" (Besnier 2000:467). In Tuvaluan, one circumstance that favors such marking is when the subject of the clause is preverbal; thus, the increase in frequency of preverbal subjects may have triggered the regularization of the Cia suffix into a marker of transitivity on all verbs. The use of the $e$ preposition specifically to mark postverbal transitive subjects could similarly be related to the fact that, in ergative languages such as Samoan and Tuvaluan, fronted transitive subjects normally do not take the ergative marker, and so when preverbal subjects became the norm, the $e$ marker "stayed behind" as a marker of postverbal subjects only.

There are two points to be noted with regard to this suggestion. First, there are Outliers that do have SVO word order but where the Cia suffixes do not function as transitive suffixes, and so the latter is certainly not a necessary outcome of the former. The additional requirement that the original system be similar to that of present-day Tuvaluan may go some way toward accounting for this, as it is almost certain that the various Outliers have their sources in different Triangle Polynesian languages, and so would not all have started out with the same system.

Second, the overt marking of transitive verbs by means of a suffix is certainly another "Melanesian" feature that may have been influenced by contact with non-Polynesian languages. However, it seems a fairly implausible scenario to propose that all these languages have individually developed the same kind of system through contact with different Melanesian languages, while at the same time also independently adopting the properties of possessive marking discussed above.

If individual, contact-induced innovations are ruled out, we are left with two possibilities. One is that the structural properties shared between Vaeakau-Taumako, Emae, IfiraMele, and Futuna-Aniwa are indicative of a shared ancestry, that is, they are either shared retentions from Proto-Polynesian, or shared innovations in a common ancestor language. This does not necessarily have to support Capell's idea of the Outliers being early "dropouts" from the original eastward migration, that is, populations that reached their present locations before the settlement of present-day Triangle Polynesia. They may well be the descendants of some Triangle Polynesian population that migrated westward at a later stage, though it should be noted that this requires the source language to have later lost the features of direct possession and prenominal inalienable possessives, as no language of Triangle Polynesia appears to show these properties today. 
Alternatively, the shared properties result from contact between the Outlier populations. This is not, as such, unlikely since, as previously mentioned, there is considerable evidence of sustained contact between various Outlier communities. It does, however, raise the question of why the group consists of just these four languages, more specifically, why it includes Vaeakau-Taumako but not the other Outliers of Temotu Province, Tikopian, and Anutan.

Part of the explanation may be related to the fact that the Vaeakau-Taumako community was the backbone of the traditional trade network that extended throughout Temotu Province until the first half of the twentieth century. The ocean-going canoes that were used in the trading voyages were built on Taumako and sold to the Polynesians in Vaeakau (the Outer Reef Islands), who then used them in trade voyages throughout the region. It must be noted, however, that the Vanuatu Outliers are situated at a considerable distance from Temotu Province: all are located in the central and southern part of the Vanuatu archipelago. While it is not implausible that the Vaeakau-Taumako speakers would have maintained some links with the Vanuatu Outlier communities, it seems unlikely that they would have traveled the distance frequently, and the Vanuatu Outliers were certainly not part of the regular trade route as described in Davenport (1964). Why Vaeakau-Taumako would show such close parallels with the fairly distant Vanuatu Outliers, which are not shared by the geographically much closer Tikopian and Anutan, ${ }^{6}$ cannot easily be explained as a function of contact alone. It must be noted, however, that Anuta, in particular, appears to have a highly complex settlement history that includes a period of abandonment followed by resettlement (Kirch 1984); such processes may, of course, have erased any original parallel features.

The explanations of shared origin vs. contact are, of course, in no way mutually exclusive. If the parallels stem from an original common source, they may have been maintained and reinforced through contact while being lost in other languages.

Bayard (1976) suggests that the Vanuatu Outliers and West Uvean were settled from another Outlier, which he presumes to have been Tikopia/Anuta "or less likely from TAU-PIL [Vaeakau-Taumako, author's note]” (Bayard 1976:80). The data presented here might be considered as tentative support for the latter scenario, as the Vanuatu Outliers show much clearer parallels with Vaeakau-Taumako than with Tikopian or Anutan on the features discussed in this paper. As regards the position of West Uvean relative to the rest of these languages, recall that it is closely similar with respect to the use of the Cia suffixes, but lacks directly possessed kin terms (with one exception) and an alienableinalienable distinction in the possessive pronoun system; ${ }^{7}$ see also Clark (1986) on connections between West Uvean and the Vanuatu Outliers.

In conclusion, the limited set of grammatical features discussed in this paper point to a close historical association between Vaeakau-Taumako and the Vanuatu Outliers, and

6. It should be noted that Tikopian does show direct possessive marking of some kinship terms (Pawley 1967:262), and possibly even a distinct set of prenominal possessive pronouns for inalienable possession. Anutan, on the other hand, shows neither.

7. It may be noted that the contact situation for West Uvean is somewhat unusual from an Outlier perspective in that it shares an island with a non-Polynesian Oceanic language, Iaai. Indirect possession in Iaai is marked by possessive classifiers preposed to the noun (Lynch 2002); it is possible that influence from Iaai may have contributed to the regularization of prenominal possessives as the unmarked pattern in West Uvean. 
may tentatively be taken as support for the proposed settlement scenario that has the Vaeakau-Taumako community as the original settlers of the Outliers further south. The ultimate source of these settlers can still only be speculated upon, though it may be noted that not just the use of the Cia suffixes and the preposition $e$, as indicated above, but also the distribution of the personal marker $a$ (Næss 2011, n.d.), is suggestive of a system derived from one similar to that found in present-day Tuvaluan as a result of the word-order change to SVO. Tuvalu is suggested as a possible source for the settlement of the Vaeakau-Taumako area both by Ward, Webb, and Levison (1973:335, 338) and Bayard (1976:84). However, saying that the grammatical systems must likely have been similar is, of course, in no way evidence for a historical link between Tuvaluan and VaeakauTaumako. What the study presented above does suggest is that, as more grammatical data from the Outliers become available, detailed comparative studies of individual structural features may provide a useful addition to lexical and phonological comparison in attempting to unravel the relationships between the Polynesian Outliers.

\section{REFERENCES}

Bauer, Winifred. 1993. Maori. London: Routledge.

Bayard, Donn. 1976. The cultural relationships of the Polynesian Outliers. University of Otago Studies in Prehistoric Anthropology 9. Department of Anthropology, University of Otago.

Besnier, Niko. 2000. Tuvaluan: A Polynesian language of the Central Pacific. London: Routledge.

Cablitz, Gabriele H. 2006. Marquesan: A grammar of space. Berlin/New York: Mouton de Gruyter.

Capell, A. 1936. The Sikayana language: A preliminary grammar and vocabulary. Journal of the Polynesian Society 45(1):9-16.

_. 1960. Anthropology and linguistics of Futuna-Aniwa, New Hebrides. Oceania Linguistic Monograph No. 5. Sydney: The University of Sydney.

. 1962. The Polynesian language of Mae (Emwae), New Hebrides. Auckland: Linguistic Society of New Zealand.

Carroll, Vern. 1965. An outline of the structure of the language of Nukuoro. Journal of the Polynesian Society 74(2):192-226.

Carroll, Vern, and Tobias Soulik. 1973. Nukuoro lexicon. Honolulu: University of Hawai'i Press

Clark, Ross. 1978. The New Hebridean Outliers. In Second International Conference on Austronesian Linguistics: Proceedings, ed. by S. A. Wurm and Lois Carrington, fascicle 2, 911-28. Canberra: Pacific Linguistics.

_. 1986. Fagauvea and the southern Outliers. Te Reo 29:113-18.

1994. The Polynesian Outliers as a locus of language contact. In Language contact and change in the Austronesian world, ed. by Tom Dutton and Darrell T. Tryon, 109-39. Berlin/New York: Mouton de Gruyter.

- 2000. Possessive markers in Polynesian languages. Sprachtypologie und Universalienforschung 53(3/4): 258-68.

_ 2002. Ifira-Mele. In The Oceanic languages, ed. by John Lynch, Malcolm Ross, and Terry Crowley, 681-93. Richmond: Curzon Press. 
Davenport, William. 1964. Social structure of Santa Cruz Island. In Explorations in cultural anthropology: Essays in honor of George Peter Murdock, ed. by Ward H. Goodenough, 57-93. New York: McGraw-Hill.

Donner, Bill. 1987. Sikaiana vocabulary: Na male ma na talatala o Sikaiana. Honiara: South Pacific Cultures Fund.

Dougherty, Janet W. D. 1983. West Futuna-Aniwa: An introduction to a Polynesian Outlier language. Berkeley: University of California Press.

Early, Robert J. 1981. Minor morphemes of the language of Tikopia. MA thesis, University of Auckland.

Elbert, Samuel H. 1965. Phonological expansions in Outlier Polynesia. Lingua 14:431-42.

- 1988. Echo of a culture: A grammar of Rennell and Bellona. Honolulu: University of Hawai'i Press.

Feinberg, Richard. 1977. The Anutan language reconsidered: Lexicon and grammar of a Polynesian Outlier, vol. 1. New Haven: Human Relations Area Files, Inc.

. 1998. Oral traditions of Anuta: A Polynesian Outlier in the Solomon Islands. New York/Oxford: Oxford University Press.

Firth, Raymond. 1985. Tikopia-English Dictionary: Taranga Fakatikopia ma Taranga Fakainglisi. Auckland: Auckland University Press.

Geraghty, Paul A. 1983. The history of the Fijian languages. Honolulu: University of Hawai'i Press.

- 2000. Possession in the Fijian languages. Sprachtypologie und Universalienforschung 53(3/4):243-50.

Kirch, Patrick V. 1984. The Polynesian Outliers: Continuity, change, and replacement. Journal of Pacific History 19:224-38.

Kirch, Patrick V., and Douglas E. Yen. 1982. Tikopia: The prehistory and ecology of a Polynesian Outlier. Bernice P. Bishop Museum Bulletin 238. Honolulu: Bernice P. Bishop Museum.

Lewis, M. Paul, ed. 2009. Ethnologue: Languages of the world. 16th ed. Dallas: SIL International.

Lichtenberk, Frantisek. 1983. Relational classifiers. Lingua 60(2/3):146-76.

Lieber, Michael D., and Kalio H. Dikepa. 1974. Kapingamarangi lexicon. Honolulu: University of Hawai'i Press.

Lynch, John. 2002. Iaai. In The Oceanic languages, ed. by John Lynch, Malcolm Ross, and Terry Crowley, 776-91. Richmond: Curzon Press.

Marck, Jeff. 1999. Revising Polynesian linguistic subgrouping and its culture history implications. In Archaeology and Language IV: Language change and cultural transformation, ed. by Roger Blench and Matthew Spriggs, 95-122. London: Routledge.

Morton, Ermel Joseph. 1962. A descriptive grammar of Tongan (Polynesian). PhD diss., Indiana University.

Mosel, Ulrike, and Even Hovdhaugen. 1992. Samoan reference grammar. Oslo: Scandinavian University Press.

Moyse-Faurie, Claire. 2000. A syntactic approach to Fagauvea. In Leo Pasifika: Proceedings of the Fourth International Conference on Oceanic Linguistics, ed. by Steven R. Fischer and Wolfgang B. Sperlich, 233-59. Auckland: Institute of Polynesian Languages and Literatures.

Næss, Åshild. 2011. Case on the margins: Pragmatics and argument marking in Vaeakau-Taumako and beyond. In Case, animacy and semantic roles, ed. by Seppo Kittilä, Katja Västi, and Jussi Ylikoski, 305-28. Amsterdam: John Benjamins.

_. N.d.. Transitivity and argument marking in Vaeakau-Taumako: A comparative Polynesian perspective. [Submitted to Transitivity and voice in Indo- 
European and beyond: A diachronic typological perspective, ed. by Leonid Kulikov and Ilja Serzants.]

Næss, Åshild, and Even Hovdhaugen. 2011. A grammar of Vaeakau-Taumako. Mouton Grammar Library 52. Berlin: De Gruyter Mouton.

Næss, Åshild, and Mathias Jenny. 2011. Who changes language? Bilingualism and structural change in Burma and the Reef Islands. Journal of Language Contact VARIA IV:217-49.

Pawley, Andrew. 1967. The relationships of Polynesian Outlier languages. Journal of the Polynesian Society 76:259-96.

- 2001. Proto Polynesian *CIA. In Issues in Austronesian morphology: A focusschrift for Byron W. Bender, ed. by Joel Bradshaw and Kenneth L. Rehg, 193-216. Canberra: Pacific Linguistics.

Ray, Sidney H. 1920. Polynesian linguistics IV. Polynesian languages of the Santa Cruz Archipelago: A note on the Tikopia language. Journal of the Polynesian Society 29:207-14.

Rutter, Lawrence Kenji. 2002. Ergative to accusative: The case of Kapingamarangi. Paper presented at the Fifth International Conference on Oceanic Linguistics, Canberra.

Salmond, Anne. 1974. A generative syntax of Luangiua, a Polynesian language. The Hauge: Mouton.

Ward, R. Gerard, John W. Webb, and M. Levison. 1973. The settlement of the Polynesian Outliers: A computer simulation. Journal of the Polynesian Society 82(4):330-42.

Wilson, William H. 1982. Proto-Polynesian possessive marking. Canberra: Pacific Linguistics.

- 2012. Whence the East Polynesians? Further linguistic evidence for a Northern Outlier source. Oceanic Linguistics 51:289-359. 
Copyright of Oceanic Linguistics is the property of University of Hawaii Press and its content may not be copied or emailed to multiple sites or posted to a listserv without the copyright holder's express written permission. However, users may print, download, or email articles for individual use. 